\title{
PENGEMBANGAN MULTIMEDIA INTERAKTIF KIMIA BERBASIS INKUIRI TERBIMBING UNTUK PEMBELAJARAN MATERI POKOK HIDROKARBON DAN MINYAK BUMI KELAS XI MIA
}

\author{
Wulan Nugraheni ${ }^{1}$, Sri Mulyani ${ }^{2}$, Ashadi $^{3}$ \\ ${ }^{1}$ Program Studi Magister Pendidikan Sains FKIP Universitas Sebelas Maret \\ Surakarta, 57126, Indonesia \\ nugraheniwulan14@gmail.com \\ ${ }^{2}$ Program Studi Magister Pendidikan Sains FKIP Universitas Sebelas Maret \\ Surakarta, 57126, Indonesia \\ srimulyaniuns@gmail.com \\ ${ }^{3}$ Program Studi Magister Pendidikan Sains FKIP Universitas Sebelas Maret \\ Surakarta, 57126, Indonesia \\ mas_ashadi@yahoo.co.id
}

\begin{abstract}
Abstrak
Penelitian ini bertujuan untuk mengetahui: (1) hasil pengembangan multimedia interaktif kimia berbasis inkuiri terbimbing pada materi hidrokarbon dan minyak bumi; (2) kelayakan multimedia interaktif kimia berbasis inkuiri terbimbing pada materi hidrokarbon dan minyak bumi; (3) efektivitas pembelajaran menggunakan multimedia interaktif kimia berbasis inkuiri terbimbing pada materi hidrokarbon dan minyak bumi. Penelitian ini merupakan jenis penelitian dan pengembangan pendidikan (educational reseach and development). Penelitian pengembangan multimedia ini menggunakan prosedur R\&D menurut Borg \& Gall yang telah dimodifikasi menjadi 9 tahap, yaitu: (1) penelitian dan pengumpulan informasi; (2) perencanaan; (3) pengembangan draft produk; (4) uji coba lapangan awal; (5) revisi hasil uji coba; (6) uji coba lapangan; (7) revisi produk hasil uji lapangan; (8) uji pelaksanaan lapangan; (9) revisi produk akhir. Analisis data yang digunakan selama proses pengembangan adalah analisis deskriptif kualitatif. Produk yang dikembangkan dalam penelitian adalah multimedia interaktif kimia berbasis inkuiri terbimbing pada materi hidrokarbon dan minyak bumi. Pengujian efektivitas multimedia dilakukan dengan membandingkan hasil belajar pada kelas eksperimen dan kelas kontrol pada masing-masing sekolah. Sampel dipilih dengan teknik cluster random sampling. Penelitian dilakukan di SMAN 2 Surakarta, SMAN 3 Surakarta, dan SMAN 8 Surakarta tahun pelajaran 2016/2017. Hasil penelitian menunjukkan bahwa (1) pengembangan multimedia interaktif kimia berbasis inkuiri terbimbing telah dilaksanakan melalui 9 tahap R\&D menurut Borg \& Gall dan telah direvisi berdasarkan saran dan masukan dari validator ahli dan praktisi, serta telah diujicobakan kepada siswa pada uji coba skala kecil, skala menengah, dan skala luas; (2) kelayakan produk multimedia dikategorikan sangat baik dan sangat layak digunakan dengan rerata persentase penilaian sebesar $86 \%$ dari validator ahli materi dan ahli media, serta $89 \%$ berdasarkan penilaian praktisi; (3) Hasil uji statistik menunjukan bahwa terdapat perbedaan yang signifikan antara hasil belajar siswa yang menggunakan multimedia interaktif yang dikembangkan (kelas eksperimen) dengan hasil belajar siswa yang tidak menggunakan multimedia (kelas kontrol). Berdasarkan rerata nilai hasil belajar kelas ekperimen yang lebih tinggi dari pada rerata nilai kelas kontrol, dapat disimpulkan bahwa produk multimedia yang dikembangkan efektif untuk meningkatkan hasil belajar aspek pengetahuan dan sikap siswa.
\end{abstract}

Kata Kunci: Multimedia Interaktif; Inkuiri Terbimbing; Hidrokarbon dan Minyak Bumi. 


\section{Pendahuluan}

Pendidikan pada dasarnya merupakan suatu proses berkelanjutan yang menuntun seseorang untuk menjadi lebih berdaya guna dan dapat menyesuaikan diri dengan lingkungannya sehingga dapat menghadapi tantangan dengan baik sesuai dengan perkembangan zaman. Saat ini merupakan era post-modern yang menuntut semua aspek kehidupan, khususnya pendidikan untuk beradaptasi dengan kemajuan Teknologi Informasi dan Komunikasi (TIK) yang berkembang dengan sangat pesat. Sejalan dengan hal itu, Kemendiknas dengan berlandaskan pada Visi Pendidikan Nasional mengupayakan pada tahun 2025 dapat menghasilkan insan Indonesia cerdas dan kompetitif, sehingga pendidikan sangat penting dalam kelangsungan kehidupan bangsa (Kemendiknas, 2010).

Kurikulum yang dikembangkan pada pendidikan formal saat ini adalah kurikulum 2013. Esensi kurikulum ini adalah proses pembelajaran harus diarahkan pada upaya untuk mengantarkan peserta didik agar mampu mengatasi setiap tantangan dalam kehidupan melalui sejumlah kompetensi yang harus dimiliki (Jufri, 2013: 43). Pembelajaran tidak lagi berorientasi teacher centered, melainkan student centered. Siswa didorong agar bersikap aktif dalam proses pembelajaran, maka pembelajaran diterapkan dengan berbasis pada penyingkapan/penemuan yang biasa disebut discovery/inquiry learning (Permendikbud, 2013).

Ilmu kimia merupakan salah satu cabang ilmu sains yang sangat berperan penting dalam kehidupan. Materi pokok hidrokarbon dan minyak bumi merupakan salah satu sub-ilmu kimia yang penting untuk dipelajari dan membutuhkan pemahaman konsep yang kuat, namun sering dianggap sulit bagi siswa. Dalam kehidupan, konsep hidrokarbon dan minyak bumi banyak diaplikasikan mulai dari rumah tangga hingga industri kimia. Meskipun demikian, masih banyak siswa yang menganggap bahwa kimia merupakan mata pelajaran yang sulit dipahami. Hal ini dapat dilihat dari Daya Serap Siswa yang menunjukkan nilai rata-rata Ujian Nasional (UN) SMA di kota Surakarta Tahun Pelajaran 2013/2014 pada kelompok soal KD Kimia Karbon adalah 49,50 sedangkan nilai rata-rata UN tingkat propinsi, dan nasional berturut- turut adalah 51,36 dan 54,82. Hal tersebut dapat digunakan sebagai tolok ukur dan menunjukkan bahwa nilai rata-rata UN SMA seSurakarta pada materi hidrokarbon dan minyak bumi belum memuaskan karena masih di bawah nilai rata-rata tingkat propinsi, dan nasional.

Berdasarkan analisis kebutuhan guru pada tiga SMA di Surakarta, yaitu SMA N 2 Surakarta, SMA N 3 Surakarta dan SMA N 8 Surakarta diketahui bahwa nilai rerata ulangan harian materi hidrokarbon dan minyak bumi pada tahun pelajaran 2014/2015 masih di bawah Kriteria Ketuntasan Minimum (KKM) masing-masing sekolah.

Fakta yang terjadi di kelas, pada proses pembelajaran, khususnya materi hidrokarbon dan minyak bumi, guru sering mengalami kesulitan dalam menyampaikan materi karena materi tersebut bersifat fakta dan mengandung banyak konsep sehingga pesan yang disampaikan guru sulit diterima oleh siswa dan cenderung monoton. Hal tersebut berdampak pada minat siswa saat mengikuti pelajaran, selanjutnya hal ini juga berpengaruh pada pemahaman siswa. Siswa menjadi kurang paham sehingga nilai yang didapat pun cenderung rendah. Ditambah lagi pembelajaran menjadi tidak optimal karena minimnya 
penggunaan media pada proses pembelajaran. Hal tersebut diperkuat dengan hasil analisis kebutuhan siswa yang menyatakan bahwa pembelajaran kimia yang dilaksanakan selama ini kurang menarik, membosankan, dan sulit dipahami. Oleh karena itu, sangatlah diperlukan adanya inovasi dalam pembelajaran.

Keberhasilan pendidikan di sekolah juga dapat diketahui dari hasil pemenuhan delapan Standar Nasional Pendidikan (SNP). Berdasarkan hasil analisis kebutuhan pada tiga SMA Negeri di Surakarta yang menerapkan Kurikulum 2013, diketahui bahwa gap terbesar terdapat pada standar proses. Gap standar proses pada SMA Negeri 2 Surakarta sebesar 3,24\%; pada SMA Negeri 3 Surakarta sebesar 1,85\%; dan pada SMA Negeri 8 Surakarta sebesar 5,09\%. Pemenuhan standar proses ini erat kaitannya dengan kualitas proses pembelajaran di sekolah-sekolah tersebut. Berdasarkan angket analisis kebutuhan guru juga diperoleh informasi bahwa guru sangat jarang menggunakan metode inkuiri pada proses pembelajaran kimia. Guru masih terbiasa dengan menerapkan metode konvensional yang lebih cenderung teacher centered. Hal tersebut menunjukkan masih rendahnya kualitas pembelajaran yang berpusat pada siswa (student centered).

Sesungguhnya, karakteristik pembelajaran kimia itu sendiri menitikberatkan pada keterampilanketerampilan proses sains (BSNP, 2006). Pembelajaran kimia hendaknya diawali dari mengamati adanya fenomena, mengkonseptualisasi, lalu menyimbolkan. Salah satu model pembelajaran yang berorientasi pada pengembangan keterampilan proses sains, yaitu pembelajaran inkuiri. Menurut Sanjaya (2009), inkuiri merupakan model pembelajaran yang menekankan pada proses berpikir secara kritis dan analitis, untuk mencari dan menemukan sendiri jawaban dari suatu masalah yang dipertanyakan. Hasil penelitian (Matthew \& Kenneth, 2013) menyatakan bahwa siswa yang diajar menggunakan metode pembelajaran inkuiri terbimbing memiliki prestasi yang lebih baik dari pada siswa yang belajar dengan menggunakan metode pembelajaran konvensional. $\mathrm{Hal}$ tersebut semakin menguatkan penulis untuk menggunakan metode inkuiri terbimbing dalam penelitian ini. Pada materi hidrokarbon dan minyak bumi yang bersifat fakta dan mengandung banyak konsep yang bersifat abstrak akan tepat dan menarik jika pembelajaran dapat dilaksanakan dan divisualisasikan dengan menggunakan media berbasis komputer yang bersifat interaktif. Hal ini sesuai dengan pemilihan media menurut isi pelajaran, dimana komputer memberikan persentase tinggi kecocokan media dengan isi materi pelajaran yang bersifat fakta, mengandung banyak konsep, dan prosedural (Arsyad, 2013). Berdasarkan Computer Technology Research (CTR) diketahui bahwa orang hanya mampu mengingat $50 \%$ dari yang dilihat dan didengar, sedangkan dapat mencapai $80 \%$ dari apa yang dilihat, didengar dan dilakukan sekaligus. Seperti yang kita ketahui bahwa multimedia interaktif dapat menyajikan informasi yang dapat dilihat, didengar, dan dilakukan. Oleh karena itu, multimedia sangatlah efektif untuk menjadi alat yang lengkap dalam prose pengajaran dan pembelajaran (Munir, 2013).

Fakta di lapangan, sekarang ini siswa lebih tertarik dengan media yang memuat tulisan yang disertai gambar, suara dan animasi gerak sehingga pemanfaatan multimedia dalam pembelajaran sangat diperlukan. Hal 
ini juga didukung oleh prinsip pembelajaran sekarang ini yakni memanfaatan teknologi informasi dan komunikasi untuk meningkatkan efisiensi dan efektivitas pembelajaran (Permendikbud, 2013). Oleh karena itu, perlu adanya peningkatan kemampuan untuk menyesuaikan diri dengan perubahan atau inovasi proses pembelajaran, salah satunya adalah dengan memanfaatkan teknologi yang ada dalam proses pembelajaran.

Berdasarkan latar belakang yang telah diuraikan tersebut, maka perlu dilakukan penelitian mengenai pengembangan multimedia interaktif kimia berbasis inkuiri terbimbing pada materi hidrokarbon dan minyak bumi.

\section{Metode Penelitian}

Tahap pengembangan dan validasi produk dilaksanakan di Magister Pendidikan Sains, Fakultas Keguruan dan Ilmu Pendidikan, Universitas Sebelas Maret Surakarta. Tempat pelaksanaan uji coba lapangan produk adalah di SMA Negeri 2 Surakarta, SMA Negeri 3 Surakarta, dan SMA Negeri 8 Surakarta. Penelitian dilaksanakan dari bulan Mei 2016 sampai dengan Agustus 2016 yang secara garis besar dibagi menjadi tiga tahap, yaitu: tahap persiapan, pelaksanaan penelitian, dan penyusunan laporan.

Penelitian yang dilakukan merupakan penelitian pengembangan (Research and Development). Model ini merupakan model penelitian yang digunakan untuk menghasilkan produk tertentu dan menguji efektivitas produk tersebut.

Penelitian pengembangan dalam penelitian ini yaitu pengembangan multimedia interaktif kimia berbasis inkuiri terbimbing untuk pembelajaran materi pokok hidrokarbon dan minyak bumi. Langkah penelitian mengacu pada penelitian dan pengembangan menurut Borg \& Gall.

Borg \& Gall (1983:772) menyatakan bahwa pendekatan penelitian dan pengembangan merupakan penelitian yang berorientasi untuk mengembangkan dan memvalidasi produk-produk yang digunakan dalam penelitian. Prosedur penelitian pengembangan yang dilakukan adalah sesuai dengan langkah-langkah berdasarkan model prosedural yang ditetapkan sebagaimana dijelaskan pada Gambar 3.1. Langkah-langkah siklus $R \& D$ yang diadaptasi berdasarkan Borg \& Gall (1983:775) sampai pada tahap kesembilan, yaitu: (1) melakukan penelitian dan pengumpulan informasi (Research and information collection; (3) mengembangkan bentuk awal produk (Develop preliminary form of product); (4) melakukan uji lapangan awal/uji coba kelompok kecil (Preliminary field testing); (5) melakukan revisi terhadap produk utama (Main product revision); (6) melakukan uji lapangan utama (Main field testing); (7) melakukan revisi terhadap produk utama (Operational product revision); (8) melakukan uji lapangan operasional (Operational field testing); (9) melakukan revisi terhadap produk akhir (Final product revision); (10) mendeseminasikan dan mengimplementasikan produk (Dissemination and implememtasion), pada tahap ke sepuluh tidak dilakukan karena peneliti sulit mencari responden.

Langkah-langkah penelitian dan pengembangan multimedia interaktif kimia berbasis inkuiri terbimbing diatas secara rinci dijelaskan sebagai berikut: Pertama, analisis studi literatur. Pada tahap penelitian dan pengumpulan informasi dilakukan melalui studi literatur dan studi lapangan. Studi literatur digunakan untuk mengumpulkan berbagai 
informasi terkait pengembangan produk multimedia interaktif kimia berbasis inkuiri terbimbing melalui kajian pustaka dan hasil penelitian yang relevan. Kedua, analisis studi lapangan. Studi lapangan dilakukan untuk memperoleh informasi tentang kebutuhan diperlukan berkaitan dengan analisis kebutuhan terhadap guru, siswa, media pembelajaran, dan sarana pembelajaran lainnya. Subyek dalam uji coba dalam penelitian ini adalah siswa kelas XI MIA SMA Negeri 2 Surakarta, SMA Negeri 3 Surakarta, dan SMA Negeri 8 Surakarta. Data yang diperoleh dari uji lapangan operasional berupa data kualitatif dan data kuantitatif. Data kualitatif adalah data hasil angket validasi ahli materi, multimedia, praktisi, dan siswa yang berupa komentar dan saran. Sedangkan data kuantitatif yaitu data tentang evaluasi terhadap kelayakan isi/materi dan media, serta data hasil belajar siswa.

Untuk bisa mengetahui apakah validitas isi memenuhi syarat atau tidak, digunakan formula Gregory. Sedangkan validitas butir soal menggunakan rumus korelasi point biserial (Sudijono, 2008). Untuk mencari reliabilitas soal bentuk obyektif digunakan rumus Kuder Richardson, yaitu KR-20.

Teknik analisis data yang digunakan dalam penelitian ini adalah dengan menganalisis data secara deskriptif kualitatif. Analisis tersebut menyajikan informasi tentang data penelitian yang meliputi analisis kebutuhan, kelayakan produk dari para validator, respon siswa dan guru, keterlaksanaan sintaks inkuiri terbimbing, serta data tes hasil belajar siswa.

Data kualitatif yang diperoleh dari kegiatan identifikasi sekolah, kurikulum, siswa, guru dan produk yang akan dikembangkan yang berasal dari tahap penelitian dan pengumpulan informasi dianalisis secara deskriptif dan digunakan sebagai acuan untuk menyusun multimedia interaktif kimia berbasis inkuiri terbimbing. Sedangkan data hasil uji coba awal, uji coba lapangan, dan uji coba operasional digunakan sebagai dasar untuk perbaikan multimedia interaktif kimia berbasis inkuiri terbimbing yang dikembangkan. Data hasil analisis kebutuhan dan uji coba ini akan dijelaskan secara deskriptif kualitatif dalam pembahasan.

Data hasil penilaian dari ahli materi, ahli media, praktisi, serta respon siswa dan guru dianalisis secara deskriptif kuantitatif dan selanjutnya diperoleh gambaran tentang multimedia interktif kimia berbasis inkuiri terbimbing berdasarkan indikator penilaiannya dengan persentase dan penskoran berdasarkan skala Likert.

Analisis data yang digunakan pada tahap uji coba efektivitas yang meliputi data hasil belajar aspek pengetahuan dan sikap siswa. Dari data yang telah diperoleh terlebih dahulu dilakukan uji prasyarat analisis yang meliputi uji normalitas dan homogenitas. Setelah didilakukan uji prasyarat analisis lalu dilanjutkan dengan menggunakan uji-t dua sampel tidak berhubungan (Independent Samples t-test).

\section{Hasil Penelitian dan Pembahasan}

\section{Pengembangan Produk Multimedia Interaktif Kimia Berbasis Inkuiri Terbimbing untuk Pembelajaran Materi Pokok Hidrokarbon dan Minyak Bumi}

Pengembangan produk multimedia interaktif kimia berbasis inkuiri terbimbing dikembangkan sesuai prosedur pengembangan Borg dan Gall (1983) hingga tahap kesembilan. 
Tahapan pertama melakukan penelitian dan pengumpulan informasi yang didalam terdiri dari analisis studi literatur, studi lapangan dan kurikulum. Tahapan ini bertujuan untuk mengidentifikasi masalahmasalah yang ada dalam proses pembelajaran dan menjadi dasar untuk menentukan dan merancang produk yang akan dibuat. Pemilihan ketiga sekolah berdasarkan kategori sekolah, yaitu kategori tinggi (baik) dan kategori kurang (rendah). Hal ini seperti modifikasi penelitian dan pengembangan Borg dan Gall yang dilakukan oleh Sukmadinata, et al (2010) yang mengambil sampel sekolah berdasarkan kategori tinggi, sedang, dan rendah. Akan tetapi, penelitian ini hanya mengambil sampel sekolah kategori tinggi dan rendah karena peneliti berasumsi jika produk dapat digunakan pada sekolah kategori tinggi dan rendah, maka produk juga dapat digunakan pada sekolah kategori sedang.

Berdasarkan hasil SNP di SMAN 2 Surakarta, diperoleh hasil capaian pemenuhan 8 SNP sebesar 88,89\% dengan kategori sangat baik. Akan tetapi, terdapat GAP antara skor ideal dengan skor implementasi, dan kesenjangan tertinggi terdapat pada standar 2 (standar proses) dengan GAP sebesar 3,24\%. Kemudian, Berdasarkan hasil wawancara SNP di SMAN 3 Surakarta diperoleh hasil capaian pemenuhan 8 SNP sebesar 91,67\% dengan kategori sangat baik. Namun, terdapat GAP antara skor ideal dengan skor implementasi dan GAP tertinggi terdapat pada standar proses dengan GAP sebesar 1,85\%. Nilai
GAP pada standar proses berhubungan dengan proses belajar mengajar, antara lain metode pembelajaran dan media pembelajaran. Demikian juga berdasarkan hasil SNP di SMAN 8 Surakarta diperoleh hasil capaian pemenuhan 8 SNP adalah $80,56 \%$ dengan kategori baik. Namun, terdapat GAP antara skor ideal dengan skor implementasi, dan kesenjangan tertinggi terdapat pada standar proses dengan GAP sebesar 5,09\%.

Pada tahapan ini juga dilakukan analisis kebutuhan pada beberapa guru dan siswa di SMAN 2 Surakarta, SMAN 3 Surakarta, dan SMAN 8 Surakarta. Data hasil wawancara dan angket analisis kebutuhan dengan guru kimia ini terkait dengan penggunaan media pembelajaran berbasis ICT, serta data angket kebutuhan siswa terkait dengan penggunaan media pembelajaran berbasis ICT di lingkungan SMA N 2 Surakarta, SMA N 3 Surakarta, dan SMA N 8 Surakarta. Berdasarkan hasil analisis angket kebutuhan guru dan siswa maka diperoleh kesimpulan bahwa diperlukan media interaktif kimia berbasis inkuiri terbimbing untuk mencapai tujuan pembelajaran.

Materi yang dipilih adalah materi hidrokarbon dan minyak bumi. Hal ini berdasarkan rerata nilai ulangan harian pada tahun sebelumnya yang masih rendah berdasarkan hasil wawancara dengan guru kimia dan diperkuat dengan hasil Daya Serap UN siswa SMA N 2 Surakarta, SMA N 3 Surakarta, dan SMA N 8 Surakarta pada materi hidrokarbon dan minyak bumi yang tergolong masih rendah.

Tabel 4.1 Nilai Rata-rata Ujian Nasional 
Tahun Pelajaran 2013/2014 pada kelompok Soal Kimia Karbon

Saat ini kurikulum yang dikembangkan pada sebagian besar SMA di Surakarta adalah kurikulum 2013. Dalam kurikulum 2013 terdapat kompetensi inti (KI), kompetensi dasar (KD), dan indikator pembelajaran. Kompetensi Inti (KI), Kompetensi Dasar (KD), dan indikator pembelajaran untuk materi hidrokarbon dan minyak bumi.

Desain pengembangan
produk meliputi tahap perencanaan dan pengembangan bentuk awal produk. Perencanaan dimulai dengan menterjemahkan pokok bahasan dan tujuan pembelajaran serta waktu yang dibutuhkan di tiap-tiap pokok bahasan, mengurutkan unit bahasan sesuai tujuan pembelajaran, merancang story board desain multimedia yang akan dikembangkan, dan mengumpulkan materi hidrokarbon dan minyak bumi dari berbagai sumber untuk memperoleh gambaran keseluruhan hal apa saja yang akan dimasukkan dalam media pembelajaran. Pada tahap ini, peneliti kemudian mengumpulkan bahan-bahan pendukung berdasarkan flowchart dan storyboard seperti foto, audio, animasi, dan gambar yang selanjutnya semua bahan yang telah terkumpul dimasukkan ke dalam format word ke stagetool dan didistribusikan ke dalam screen dengan menggunakan aplikasi grafis Macromedia flash dengan mengacu pada flowchart dan storyboard. Multimedia didesain dengan tujuan agar dapat digunakan sebagai media pembelajaran yang berbasis inkuiri terbimbing dan dimaksudkan dapat digunakan saat pembelajaran baik di kelas maupun secara mandiri. Multimedia interaktif sebagai media pembelajaran lebih ditekankan untuk memberikan pemahaman materi secara jelas dan menarik sehingga meningkatkan minat belajar siswa terhadap materi hidrokarbon dan minyak bumi. Multimedia interaktif kimia berbasis inkuiri terbimbing dirancang berdasarkan tahapan inkuiri terbimbing menurut Sanjaya (2009), yaitu: orientasi, perumusan masalah, pengajuan hipotesis, pengujian hipotesis, dan perumusan kesimpulan.

\section{Kelayakan Multimedia Interaktif} Kimia Berbasis Inkuiri Terbimbing yang Dikembangkan Kelayakan multimedia interaktif kimia berbasis inkuiri terbimbing dikembangkan melalui tahap validasi ahli, penilaian oleh praktisi pendidikan, dan siswa sebagai kelompok uji coba awal, uji coba lapangan dan uji pelaksanaan lapangan. Hasil penilaian produk oleh ahli media, materi dan praktisi diperoleh produk dengan kategori layak dengan revisi. Multimedia interaktif kimia berbasis inkuiri terbimbing menggunakan aplikasi Macromedia flash pada materi hidrokarbon dan minyak bumi selanjutnya diujicobakan pada uji coba kelompok kecil. Siswa yang dilibatkan pada ujicoba ini berjumlah 12 siswa kelas XI dari tiga sekolah atau 4 siswa dari masing-masing sekolah. Tujuan dari uji coba kelompok kecil adalah untuk mengumpulkan informasi yang dapat digunakan sebagai bahan untuk memperbaiki 
produk dalam revisi selanjutnya. Saran yang diberikan siswa, antara lain suara pada video kurang keras, terdapat jenis font yang sulit dibaca, dan animasi tombol "back" pada bagian isi materi ada yang belum jalan. Berdasarkan hasil penilaian siswa rerata persentase kelayakan sebesar 80\% dengan kategori baik. Hal ini berarti penggunaan produk multimedia interaktif kimia berbasis inkuiri terbimbing yang dikembangkan diharapkan dapat menunjang kegiatan pembelajaran pada materi materi hidrokarbon dan minyak bumi. Hal ini didukung oleh pernyataan Munir (2013) bahwa multimedia sangatlah efektif menjadi alat yang lengkap dalam proses pembelajaran karena multimedia dapat menyajikan informasi yang dapat dilihat, didengar, dan dilakukan. Karena hasil penilaian dalam kategori baik, hal ini berarti produk baik dan layak digunakan untuk tahapan selanjutnya dengan beberapa perbaikan. Setelah perbaikan dilakukan berdasarkan saran dan masukan dari siswa, maka didapatkan draft III. Tahap selanjutnya, draft III ini di uji cobakan pada skala menengah.

Uji coba lapangan skala menengah tidak dilaksanakan pada tiga sekolah, tetapi hanya di SMAN 2 Surakarta. Penyebabnya adalah alokasi waktu untuk materi hidrokarbon dan minyak bumi di SMAN 2 Surakarta dimulai lebih dahulu dari pada di SMAN 3 Surakarta dan SMAN 8 Surakarta. Pada tahap uji coba lapangan dilakukan eksperimen dengan melibatkan 2 kelas yang diberi perlakuan berbeda. Sebelumnya dilakukan tes kesetaraan awal pada kelas eksperimen dan kelas kontrol pada SMA Negeri 2. Tes kesetaraan dilakukan untuk mengetahui kesetaraan kemampuan awal siswa dari kedua kelas tersebut sebelum dilakukan eksperimen. Dari hasil tes kesetaraan tersebut, diperoleh bahwa kedua kelas mempunyai nilai rerata yang setara. Oleh karena itu, kedua kelas layak untuk dibandingkan. Subyek pada uji coba lapangan ini adalah 48 siswa kelas XI.MIA.1 dan XI.MIA.5 SMA N 2 Surakarta. Kelas XI.MIA.1 digunakan sebagai kelas eksperimen. Subyek pembelajaran kelas eksperimen adalah 24 siswa kelas XI.MIA.1 di SMA Negeri 2 Surakarta. Pada hari sebelumnya peneliti telah memberikan CD pembelajaran dan pengarahan tentang tata cara penggunaan multimedia interaktif kimia berbasis inkuiri terbimbing dengan aplikasi Macromedia Flash. Guru dapat mengelola kelas dengan baik sehingga tetap kondusif, proses pembelajaran sesuai dengan yang direncanakan pada RPP, dan banyak siswa yang antusias pada pertemuan pertama pembelajaran materi hidrokarbon dan minyak bumi. Hasil tersebut sesuai dengan hasil penelitian (Heidig et al., 2015) yang menyatakan bahwa pembelajaran menggunakan multimedia terbukti tidak hanya meningkatkan ranah pengetahuan saja, tetapi motivasi siswa dalam menerima pembelajaran juga meningkat. Keterlaksanaan pada tahap analisis data ini, berdasarkan hasil pengamatan baik kepada guru maupun siswa mendapatkan nilai yang tinggi, yaitu 3,5. Keterlaksanaan setiap langkah pada sintaks inkuiri terbimbing ini dapat berhasil ini tidak lepas dari peran guru sangat penting dalam membimbing siswa untuk melakukan prosedur ilmiah tersebut 
sehingga tujuan pembelajaran dapat tercapai.

Hasil belajar pengetahuan dan sikap siswa yang telah diketahui berdistribusi normal dan berasal dari populasi yang homogen. Selanjutnya, efektivitas pembelajaran kedua kelas dapat diukur dengan menggunakan uji-t dua sampel tidak berhubungan (Independent Samples t-test). Hasil analisis uji-t menunjukkan taraf signifikasi kurang dari 0,05, maka keputusan uji Ho ditolak. Hal ini berarti terdapat perbedaan yang signifikan antara hasil belajar (pengetahuan dan sikap) siswa kelas eksperimen dengan kelas kontrol.

Apabila dilihat dari nilai reratanya, nilai pengetahuan dan sikap kelas eksperimen lebih besar daripada kelas kontrol sehingga dapat disimpulkan bahwa penggunaan multimedia interaktif berbasis inkuiri terbimbing yang dikembangkan lebih efektif untuk dilaksanakan pada pembelajaran hidrokarbon dan minyak bumi. Hal tersebut sesuai dengan hasil penelitian Strom (2012) yang menunjukkan bahwa metode inkuiri terbimbing dapat meningkatkan pengetahuan dan mengembangkan ketrampilan proses siswa, yaitu ketrampilan melakukan pengamatan, bertanya, dan berkomunikasi. Hasil tersebut juga diperkuat oleh hasil penelitian Özdilek \& Bulunuz (2009) bahwa inkuiri terbimbing yang merupakan kegiatan ilmiah, terbukti efektif untuk mengembangkan sikap siswa terhadap ilmu pengetahuan dan pengajaran.

Hasil angket kelayakan produk ini diperoleh persentase nilai sebesar $81 \%$ dengan kategori sangat baik dan layak untuk digunakan. Pada tahapan ini tidak dilakukan perbaikan karena tidak terdapat saran perbaikan dari siswa. Pada tahap ini didapatkan draft IV produk. Selanjutnya, draft IV produk ini diujicobakan pada uji coba lapangan skala luas.

\section{Efektivitas Multimedia Interaktif Kimia Berbasis Inkuiri Terbimbing untuk Pembelajaran Materi Pokok Hidrokarbon dan Minyak Bumi}

Tahap uji pelaksanaan lapangan skala luas ini dilakukan pada SMAN 3 Surakarta dan SMAN 8 Surakarta. Kelompok perlakuan pada SMAN 3 Surakarta terdiri dari kelas eksperimen II dan kelas kontrol II, sedangkan kelompok perlakuan pada SMA N 8 Surakarta terdiri dari eksperimen III dan kelas kontrol III. Pada langkah uji skala luas ini hampir sama yang dilakukan pada uji skala menengah. Pada uji efektivitas produk pada skala luas ini, peneliti membandingkan siswa yang melakukan pembelajaran menggunakan multimedia interaktif berbasis inkuiri terbimbing dengan siswa yang melakukan pembelajaran tanpa menggunakan multimedia interaktif. Penilaian mencakup aspek pengetahuan dan sikap. Nilai yang diperoleh pada kelas eksperimen dan kelas kontrol diolah dengan menggunakan software SPSS18. Dari perhitungan pada aspek pengetahuan, diketahui bahwa data yang diperoleh normal dan homogen. Analisis deskriptif dilakukan dengan uji-t dua sampel tidak berhubungan (Independent Samples t-test) dengan menggunakan software SPSS18. Pada eksperimen di SMA N 3 Surakarta, hasil perhitungan uji-t aspek pengetahuan diperoleh data, yaitu 0,013 . Sedangkan hasil uji-t aspek pengetahuan di SMA $\mathrm{N} 8$ Surakarta diperoleh data 0,000 . Karena sig $<0,05$, hal ini berarti 
Ho ditolak, maka dapat disimpulkan bahwa nilai rerata aspek pengetahuan kelas eksperimen dan kelas kontrol baik di SMA Negeri 3 Surakarta maupun di SMA N 8 Surakarta terdapat perbedaan yang signifikan. Berdasarkan nilai yang diperoleh, dapat dapat diketahui bahwa pada kedua sekolah tersebut nilai rerata kelas eksperimen lebih tinggi dibanding kelas kontrol.

Selanjutnya, hasil perhitungan pada aspek sikap pada SMA N 3 Surakarta menunjukkan bahwa data normal dan homogen. Dengan demikian, analisis dilanjutkan menggunakan dengan uji-t dua sampel tidak berhubungan (Independent Samples t-test) menggunakan program SPSS18. Dari perhitungan nilai sikap pada kelas eksperimen dan kelas kontrol SMA N 3 Surakarta diperoleh Sig. $<0,05$. Hal ini berarti bahwa nilai rerata baik aspek sikap pada kelas eksperimen dan kelas kontrol di SMA Negeri 3 Surakarta terdapat perbedaan yang signifikan. Bila dilihat dari rerata nilainya, kelas eksperimen memiliki nilai rerata yang lebih tinggi. Berbeda halnya dengan hasil perhitungan nilai sikap pada kelas eksperimen dan kelas kontrol SMA N 8 Surakarta dengan uji-t, diperoleh signifikansi Sig.>0,05. Hal ini berarti tidak terdapat perbedaan nilai sikap yang signifikan antara kelas eksperimen dan kelas kontrol pada SMA N 8 Surakarta.

Berdasarkan hasil penelitian ini, terlihat bahwa pembelajaran menggunakan multimedia interaktif kimia berbasis inkuiri terbimbing yang telah dikembangkan efektif untuk gunakan pada pembelajaran kimia, khususnya materi hidrokarbon dan minyak bumi.
Kemajuan ilmu pengetahuan dan teknologi sekarang ini sudah masuk dalam dunia pendidikan. Oleh karena itu dibutuhkan perspektif global dalam kurikulum pendidikan. Pendidikan global merupakan sebuah gerakan sosial kontemporer yang mengarah pada perkembangan ilmu pengetahuan yang sangat cepat di seluruh dunia (Mulyanto cit Sari, 2010). Pendidikan dalam perspektif global menekankan pada kurikulum dengan aspek kajian luas, diharapkan output tidak hanya untuk memenuhi standar nasional, tetapi juga dapat bersaing dan memenuhi tantangan global.

Kurikulum 2013 yang diterapkan saat ini menghendaki adanya perspektif global di dalam proses pembelajaran. Struktur kurikulum 2013 tidak mengikutsertakan mata pelajaran Teknologi Informasi dan Komunikasi (TIK) secara khusus menjadi mata pelajaran di sekolah dasar dan menengah. Akan tetapi, mata pelajaran TIK harus dapat terintegrasi pada semua mata pelajaran. Oleh karena itu, keterampilan dalam menggunakan perangkat Teknologi Informasi dan Komunikasi mutlak diperlukan demi kelancaran proses pembelajaran. Siswa akan dapat mengeksplorasi pengetahuannya dari perangkat TIK sehingga pengetahuannya lebih luas karena siswa mendapatkannya dari banyak sumber, bukan hanya satu guru. Apalagi peran guru menurut kurikulum 2013 adalah sebagai fasilitator yang membimbing siswa untuk dapat menemukan dan membangun konsep pengetahuannya sendiri.

Kolaborasi antara ilmu pengetahuan dan teknologi yang diterapkan di dalam pembelajaran 
berupa multimedia interaktif berbasis inkuiri terbimbing ini berkontribusi dalam mewujudkan kurikulum pendidikan di Indonesia menjadi semakin berwawasan global dan dapat menghadapi tantangan global. Seperti halnya dengan pernyataan Kuhlthau (2010) bahwa perkembangan ilmu pengetahuan dan teknologi semakin lama akan semakin maju sehingga dapat mendorong upaya-upaya pembaharuan dalam pemanfaatan hasil-hasil teknologi dalam proses belajar.

Penyempurnaan produk akhir diperoleh setelah mendapatkan saran/masukan berdasarkan angket respon siswa dan guru terhadap kelayakan produk pada skala luas. Angket respon siswa diberikan pada 62 anak kelas eksperimen dan angket respon guru diberikan pada 2 orang guru kimia dari dua sekolah. persentase ketercapaian pada aspek pembelajaran, materi dan media mengalami peningkatan dibandingkan pada uji coba lapangan skala menengah. Hal ini menunjukkan proses pembelajaran menggunakan multimedia interaktif kimia berbasis inkuiri terbimbing berjalan lebih baik yang terbukti dari pengamatan keterlaksanaan sintak inkuiri terbimbing yang juga mengalami kenaikan skor.

Berdasarkan ketiga aspek penilaian, aspek dengan persentase ketercapaian paling tinggi adalah aspek media sebesar $85 \%$. Hal ini berarti produk multimedia interaktif kimia berbasis inkuiri terbimbing ini juga disambut dengan baik oleh siswa. Hal ini diperkuat dengan pernyataan Santosa (2010) bahwa pembelajaran dengan multimedia terbukti dapat menarik perhatian siswa karena adanya kombinasi dari berbagai aspek baik suara, animasi, dan warna yang berbeda-beda sehingga media terasa lebih hidup. Aspek penilaian dengan persentase ketercapaian terendah adalah aspek materi. Walaupun demikian, aspek ini sudah mengalami kenaikan persentase dibanding uji coba skala menengah. Pada tahapan penyempurnaan produk akhir ini didapatkan saran dari respon guru yakni isi materi akan semakin baik jika lebih diperkaya lagi dan CD penyimpan file multimedia hendaknya diberi sampul yang didesain sehingga dapat menambah daya tarik siswa untuk menggunakan produk tersebut.

Secara keseluruhan, persentase kelayakan produk yang dinilai siswa pada uji coba skala luas ini memiliki kategori "Sangat Baik" dengan rerata $84 \%$, sedangkan persentase kelayakan produk pada angket respon guru juga mendapatkan penilaian kelayakan dengan kategori sangat baik dengan rerata sebesar $85 \%$.

\section{Kesimpulan dan Rekomendasi}

\section{Kesimpulan}

Berdasarkan hasil analisis data penelitian tentang pengembangan multimedia interaktif kimia berbasis inkuiri terbimbing pada materi hidrokarbon dan minyak bumi untuk kelas XI MIA, dapat disimpulkan bahwa:

Pertama, hasil akhir pengembangan produk melalui prosedur R\&D adalah tersusunnya multimedia interaktif kimia yang telah direvisi berdasarkan saran dan masukan dari validator dan praktisi serta telah diujicobakan kepada siswa pada uji coba skala kecil, menengah, dan luas.

Kedua, kelayakan produk yang dikembangkan dikategorikan "sangat baik" dengan persentase ketercapaian 
skor sebesar $86 \%$ berdasarkan penilaian dari validator, dan $89 \%$ berdasarkan penilaian praktisi. Produk yang dikembangkan dikatakan baik dan layak digunakan dalam pembelajaran berdasarkan angket respon siswa dengan persentase $80 \%$ pada saat uji coba awal, $81 \%$ pada saat uji coba lapangan skala menengah, $84 \%$ pada saat uji coba pelaksanaan lapangan skala luas. Produk juga dikategorikan sangat baik dengan persentase sebesar $87 \%$ berdasarkan hasil angket respon guru.

Ketiga, Berdasarkan uji efektivitas, produk yang dikembangkan efektif untuk meningkatkan prestasi belajar aspek pengetahuan dan sikap pada kategori sekolah tinggi dan rendah. Pada uji coba pelaksanaan lapangan skala luas, hasil belajar siswa pada kelas eksperimen, lebih tinggi secara signifikan daripada siswa kelas control.

\section{Rekomendasi}

Bagi guru, hendaknya guru memahami model pembelajaran inkuiri terbimbing dan karakteristik siswa terlebih dahulu, agar tujuan pembelajaran dapat tercapai secara optimal.

Bagi peneliti selanjutnya, Hasil penelitian ini dapat digunakan sebagai acuan untuk penelitian berikutnya yang sejenis dengan materi yang berbeda. Selain itu, penelitian pengembangan dapat dilanjutkan pada tahap diseminasi atau penyebarluasan produk.

Kemudian bagi siswa. Seiring berkembangnya ilmu pengetahuan dan teknologi, siswa hendaknya memanfaatkan seoptimal mungkin fasilitas yang dimiliki yaitu laptop untuk mendukung pembelajaran.

\section{Daftar Pustaka}

Amri, S \& Ahmadi I, K. 2010. Proses Pembelajaran Kreatif dan Inovatif dalam Kelas. Jakarta: Prestasi Pustakaraya.
Aunurrahman. 2011. Belajar dan Pembelajaran. Bandung: Alfabeta.

Arsyad, A. 2013. Media Pembelajaran. Jakarta: PT Raja Grafindo Persada.

Bilgin, I. (2009). The effects of guided inquiry instruction incorporating a cooperative learning approach on university students' achievement of acid and bases concepts and attitude toward guided inquiry instruction. Scientific Research and Essay, 4(10), 1038-1046. Retrieved from

http://www.academicjournals.org/sr

Borg, W.R. dan Gall, M.D. 1983. Educational Research An Introduction. New York: Longman.

Dahar, RW. 2011. Teori-teori Belajar. Jakarta: Erlangga.

Darmawan, D. 2012. Pendidikan Teknologi Informasi dan Komunikasi. Bandung: PT. Remaja Rosdakarya

Daryanto, T. 2010. Sistem Multimedia dan Aplikasinya. Yogyakarta: Graha Ilmu.

Depdiknas. (2003). Pedoman Pengembangan Instrumen dan Penilaian Ranah Afektif. Jakarta: Direktorat Pendidikan Menengah Umum Depdiknas.

Depdiknas. 2009. Analisis Butir Soal. Jakarta: Direktorat Pendidikan Menengah Umum. Fessenden, RJ \& Fessenden, JS. 1986. Organic Chemistry, Third Edition. USA: Wadworth Inc.

Gulo, W. 2002. Strategi Belajar Mengajar Jakarta: Grasindo

Guilford, J.P. 1956. Fundamental Statistics in Psychology and Education. New York: McGraw Hill.

Hamdani. 2011. Strategi Belajar Mengajar. Bandung: Pustaka Setia

Hart, H., et al. 2003. Organic Chemistry. Houghton: Houghton Mifflin Company.

Hasrul. 2010. Langkah-Langkah Pengembangan Multimedia 
Interaktif. Jurnal MEDTEK, Volume 3, No.1.

Heidig, S., Müller, J., \& Reichelt, M. (2015). Emotional design in multimedia learning: Differentiation on relevant design features and their effects on emotions and learning. Computers in Human Behavior, 44, 8195.https://doi.org/10.1016/j.chb.201 4.11.f 009

Ifeoma, O. E., \& Oge, E. K. (2013). Effects of Guided Inquiry Method on Secondary School Students' Performance in Social Studies Curriculum in Anambra State, Nigeria, 3(3), 206-222.

Jufri, W. 2013. Belajar dan Pembelajaran Sains. Bandung: Pustaka Rineka Cipta

Kosasih, E. 2014. Strategi Belajar dan Pembelajaran. Bandung: Yrama Widya.

Kemendiknas. 2010. Renstra Kemendiknas. Jakarta: Kemendiknas.

Kuhlthau, C. C. (2010). Call for 21 st Century Skills Information Technology - The Easy Part and the Hard Part. School Libraries Worldwide, 16(1), 17-28.

Kuhlthau, C., Maniotes, L., \& Caspari, A. (2012). Guided inquiry design: A framwork fo inquiry in your school. The Journal of the New Members Round Table, 4(1).

Matthew, B., \& Kenneth, I. O. (2013). a Study on the Effects of Guided Inquiry Teaching Method on Students Achievement in Logic. International Researcher, 2(1), 135-140.

Molenda, et al., 1996. Instructional media and technologies for learning (5 th). Englewood Cliff, New Jersey : Prentice Hall, Inc.

Mulyasa, E. 2004. Kurikulum Berbasis Kompetensi, Konsep, Karakteristik, dan Implementasi. Bandung: PT Remaja Rosdakarya.

Munir. 2013. Multimedia Konsep \& Aplikasi dalam Pendidikan. Bandung: Alfabeta.

Neo, M., \& Neo, K. T. K. (2001). Innovative teaching: Using multimedia in a problem-based learning environment. Educational Technology \& Society, 4(4), 19-31. Retrieved from http://www.ifets.info/journals/4 4/n eo.ht ml

Özdilek, Z., \& Bulunuz, N. (2009). The effect of a guided inquiry method on pre- service teachers' science teaching self- efficacy beliefs. Journal of Turkish Science Education, 6(2), 24-42.

Prabowo, A. 2012.Panduan Kreatif Membuat Bahan Ajar Inovatif. Yogyakarta: Diva Press.

Riduwan.2008. Skala Pengukuran Variabelvariable Penelitian, Bandung: Alfabeta

Roestiyah. 2008. Strategi Belajar Mengajar. Jakarta: Rineka Cipta

Santoso, S. 2010. Belajar dan Faktor-faktor yang Mempengaruhinya. Jakarta: Rineka Cipta

Sari, IG. 2014. Pengembangan Multimedia Interaktif Berbasis Inkuiri Terbimbing melalui Animasi Flash pada Pokok Bahasan Sistem Ekskresi SMAN 1 Andong. Tesis. Universitas Sebelas Maret.

Sastrohamidjojo, H. 2014. Kimia Organik Dasar. Yogyakarta: UGM Press

Schoffstall, A. M., \& Gaddis, B. a. (2007). Incorporating Guided-Inquiry Learning into the Organic Chemistry Laboratory. Journal of Chemical Education, 84(5), 848. https://doi.org/10.1021/ed084p848

Setyosari, P. 2012. Metode Penelitian Pendidikan dan Pengembangan. Jakarta: Kencana Prenada Media Group.

Slameto. 2010. Belajar dan Faktor-faktor yang Mempengaruhinya. Jakarta: Rineka Cipta.

Strom, R. K. (2012). Using Guided Inquiry 
To Improve Process Skills and Content Knowledge in Primary Science, (July).

Sudjana, N. 2009. Penilaian Hasil Proses Belajar Mengajar. Bandung: Remaja Rosdakarya.

Sudijono, A. 2008. Pengantar Evaluasi Pendidikan. Jakarta: Raja Grafindo Persada.

Sukmadinata, NS. 2010. Metode Penelitian Pendidikan. Bandung: PT. Remaja Rosdakarya.

Sumanto. 1998. Psikologi Pendidikan, Landasan Kerja Pemimpin Pendidikan. Jakarta: Rineka Cipta.

Suwastono. 2010. Pengembangan Pembelajaran E-Learning Berbasis Moodle pada Mata Kuliah Penginderaan Jauh S-1 Jurusan Geografi Universitas Negeri Malang. Tesis. Malang: PPS UM Malang.

Triyanto. 2007. Model-model Pembelajaran Inovatif Berorientasi Konstruktivistik. Jakarta: Prestasi Pustaka.

Vaughan, T. 2011. Multimedia: Making It Work. Osborne: Mc. Graw Hill.

Warsita. 2008.Teknologi Pembelajaran. Jakarta: Rineka Cipta. 